\title{
Rick Warren, purpose driven en die 40 dae doelgerigte lewe veldtog
}

\author{
André Ungerer \& Malan Nel ${ }^{1}$ \\ Departement Praktiese Teologie \\ Universiteit van Pretoria
}

\section{Abstract}

\section{Rick Warren, purpose driven and the $\mathbf{4 0}$ days of purpose campaign}

More than 532 churches/congregations in South-Africa have already purchased "The purpose driven campaign kit" and completed the $\mathbf{4 0}$ days campaign or are planning to do so. The name Rick Warren is synonymous with "Purpose driven" and the popularity of his work as well as his influence in this country, justifie a study of this nature. This study wants to determine the effect of Rick Warren's 40 days of purpose in the circuit of Klerksdorp of the Nederduitsch Hervormde Kerk van Afrika. Warren provides five purposes for a believer in the church in his book, A purpose driven life, which according to him is the church's purpose of existence. The hypothesis of this study is that the 40 days of purpose is an excellent project for congregations to discover their purpose of existence, while it also strengthens the process of building the local congregation. Eight congregations participated in the research project.

\section{INLEIDING}

Rick Warren het feitlik ' $n$ huishoudelike naam in Suid-Afrika geword. Dit is veral deur sy boek, The purpose driven life (2002) dat hy ter plaatse bekendheid verwerf het. Voortvloeiend uit die boek, het die "Doelgerigte lewe Veldtog", Suid-Afrika soos 'n veldbrand getref. In Suid-Afrika het ongeveer 532 kerke/gemeentes sedert 2003, Purpose driven pakette aangekoop en

\footnotetext{
${ }^{1}$ Hierdie artikel is gebaseer op 'n gedeelte van die MA-verhandeling onder leiding van Prof $\mathrm{dr}$ Malan Nel, Departement Praktiese Teologie, Universiteit van Pretoria, getiteld "'n Prakties Teologiese studie vanuit 'n gemeentebouperspektief om die uitwerking te bepaal van die '40 Dae doelgerigte lewe' van Rick Warren as hulpmiddel in die Hervormde gemeentes van die Ring van Klerksdorp ten einde hulle bestaansdoel te ontdek". Dr Ungerer erken die bydrae van dr Mike van der Linde en Jeanette Pauw, Departement Statistiek, Universiteit van Pretoria.
} 
reeds die 40 Dae Doelgerigte Veldtog deurloop, of beplan om dit te doen. Die naam Rick Warren en Purpose driven is sinoniem en die populariteit van sy werk asook die invloed wat hy uitoefen in hierdie land, regverdig ' $n$ artikel van hierdie aard.

\section{RICK WARREN}

Warren het reeds van jongs af definitiewe leierseienskappe openbaar. Hy groei op in die platteland van Noord Kalifornië, die seun van 'n Southern Baptist predikant wat klein kerke gestig en bedien het (Stafford 2002:44). Tydens die hoogbloei van die "Jesus Movement" het Warren in sy hoërskooljare, skole toegespreek oor "hoe om 'n Christen klub in 'n skool uit te bou." Toe hy by California Baptist College in Riverside was het hy 'n jeuggroep opgebou met 10000 studente op 'n poslys. Hy het dit gedoen met behulp van $\$ 18,000$ (bewillig deur kerkleiers) se gewigopteltoerusting as vertrekpunt. Gedurende sy laaste skooljaar het die skool se administrasie hom gevra om 'n kursus in evangelisasie aan te bied (Stafford 2002:45).

Hy het Fort Worth's Southwestern Seminary in Texas gekies om sy teologiese opleiding te deurloop omdat hy blootstelling aan die grootste Southern Baptiste Kerke wou hê (Warren 1995:11). Nadat hy 'n meestersgraad verwerf het het hy ingeskryf vir 'n doktorsgraad by die Fuller Theological Seminary. Hy is getroud met Kay, 'n liefde wat strek van hulle sestiende lewensjaar af.

\section{PURPOSE DRIVEN}

Sy werk is geskoei op Church growth uitgangspunte wat hom voorberei het vir sy gemeentewerk en gelei het tot die boek, The purpose driven church (1995). Hy noem in die boek dat hy vir die afgelope twintig jaar 'n student is van groeiende gemeentes en dat hy honderde sulke gemeentes, ongeag hulle grootte, besoek het. Hy het in 'n stadium 'n jaar spandeer om die honderd grootste kerke in Amerika te bestudeer en noem dat hy elke boek gelees het oor kerkgroei. Daarby het hy die Nuwe Testament uit 'n kerkgroei oogpunt bestudeer: "The New Testament is the greatest church-growth book ever written ... it's the owner's manual for the church" (Warren 1995:17-18). Hoewel Warren uit die kerkgroeibeweging kom, kwalifiseer hy groei soos volg: "I believe the key issue for churches in the twenty-first century will be church health, not church growth .... Focussing on growth alone misses the point. When congregations are healthy, they grow the way God intends. Healthy churches don't need gimmicks to grow - they grow naturally" (Warren 1995:17). Warren (Stafford 2002:48) noem homself ' $n$ "Toolmaker". 
I believe that tools change the world. When Bill Bright [founder of Campus Crusade for Christ] dies, Bill Bright is going to leave the Four Spiritual laws, Ten Transferable Concepts, and the Jesus film .... [W] hen Dawson Trotman [founder of the Navigators] died, he left the hand and the wheel. When Rick Warren dies, he's going to leave the circles (Warren 1995:153) and the diamond.

(Warren 1995:144)

In kort beteken die sirkel en diamant om die gemeenskap so ver te kry om eredienste by te woon sodat hulle gereelde kerkgangers word. Dan eers deurloop hulle 'n lidmaattoerustingsprogram alvorens hulle lidmate word. Lidmate dra nou eers hulle tiende by en word deur drie ander kursusse begelei om uiteindelik in verskillende bedieninge tuis te kom. Die sirkels dui hierdie proses aan: van 'n soekende gemeenskap aan die buiterand, tot 'n kernkorps van lidmate wat deel word van verskillende bedieningspanne en sendingaksies. Die diamant dui die verskillende kursusse aan in lidmaatskap. Dit begin by klas 101, 'n beginnersklas met die oog op lidmaatskap, en eindig met klas 401 as hoogste vlak met die oogmerk - die lidmaat se sending in die wêreld (Warren 1995:121-398).

Warren wil deur middel van pastors werk om die wêreld te verander en dit word sy "stealth strategy" genoem. "Through pastors he intends to change the world" (Stafford 2002:42). Op die webtuiste (Purposedrivenlife.com) word genoem dat meer as 157000 pastors tans ingeskryf is by Rick Warren's toolbox, 'n weeklikse e-pos nuusbrief. Meer as 250000 pastors en kerkleiers van 125 lande het al die Purpose Driven seminare bygewoon wat in 18 tale aangebied word (Purpose Driven Life 2002-2005). In die VSA het Warren een van die gewildste predikante geword. Die Time Magazine van 7 Februarie 2005 het 'n artikel gehad oor die 25 invloedrykste "Evangelicals" in Amerika. 600 Senior pastors is gevra om die mense te noem wat die grootste invloed op kerksake in die VSA gehad het - Warren, naas Billy Graham se naam het die tweede plek ingeneem. Warren, is die opvolger van Billy Graham as Amerika se pastor. Merkwaardig is dat Warren $90 \%$ van sy inkomste afkomstig uit die Purpose driven life beweging skenk aan die opbou en uitbou daarvan. In 'n onderhoud gevoer met Warren deur Paul Bradshaw in 2006, word vermeld dat Warren ook die afgelope 24 jaar se inkomste wat hy by Saddelback verdien het, aan die gemeente terugbetaal het (CCNews Portal, 12 August 2006).

\subsection{Sy gemeente}

Warren het die Saddleback Church in Januarie 1980 begin met een gesin. Sy visie was om ongelowige, kerklose mense te bereik en in te skakel. Die 
afgelope 25 jaar het die gemeente merkwaardig gegroei. Vir 'n groot deel van die gemeente se bestaan is daar nie oor 'n eie kerkgebou beskik nie. Tente is opgeslaan en skole se fasiliteite is gehuur. Dit is eers in die laaste jare dat hulle eie fasiliteite bekom het. Die gemeentekompleks is tans geleë in Lake Forest wat deel vorm van die Los Angeles metropool. Meer as 22000 mense woon eredienste oor naweke by en is daar meer as 50000 name op die lidmaatregister. Saddleback is aangewys as die vinnigste groeiende Baptiste Kerk in die geskiedenis asook die grootste kerk in die Southern Baptist Convention. Die afgelope 8 jaar is meer as 10000 nuwe gelowiges gedoop en Saddleback het 34 dogterskerke gestig terwyl daar tans meer as 4000 lidmate op sendingprojekte oral in die wêreld is (Purposedrivenlife.com).

\subsection{Verkope van The Purpose Driven Church- (1995) en Life (2002)} Van Warren se boek, The purpose driven life (2002), is meer as 25 miljoen kopieë die afgelope jare verkoop en dit is die beste hardeband verkoper in die VSA se geskiedenis. Van sy eerste boek, The Purpose Driven Church, is meer as ' $n$ miljoen kopieë in 50 tale verkoop en dit is aangewys as een van die 100 Christelike boeke wat die 20ste eeu verander het. Redaksionele kommentaar in Christianity Today in 2004 wys daarop dat Purpose Driven Life (2002) die Harry Potter reeks se verkope oortref het in 2003: “... Actually, make that Harry Potter and The Da Vinci Code combined. Only when you then add the sales of The South Beach Diet to those books do you get close to matching the sales of The Purpose Driven Life." Costella (2004:2) noem dat invloedryke Christelike leiers soos Billy Graham, Franklin Graham, Bruce Wilkinson, Max Lucado en Lee Strobel sterk ondersteuners is van die Purpose Driven Life (2002) en beveel dit ook aan by hulle lesers en volgelinge. Die Doelgerigte lewe is meer as ' $n$ boek - dit het ' $n$ beweging geword - 'n gids vir die 40 dae geestelike reis.

\subsection{Basiese inhoud van Die doelgerigte lewe (2003)}

"Dit gaan nie oor jou nie." Dit is die eerste sin van Dag 1 in Warren (2003) se boek, Die doelgerigte lewe. "Jou lewensdoel is veel groter as jou persoonlike vervulling, jou innerlike vrede of selfs jou geluk ... As jy wil weet waarom jy op die planeet geplaas is, moet jy by God begin. Jy is deur sy doel en vir sy doel gebore." Dié openingsin plaas die klem heel anders as wat in meeste motivering- en selfhelpboeke gevind word. Christianity Today in 2004 lewer komies kommentaar oor die Amerikaanse spiritualiteit en die boek van Warren: "But Warren's book is intended to be merely a start, to help narcissistic Americans stop their spiritual naval-gazing." Volgens Christianity Today sal sommiges sekerlik die boek lees om verborge geluk te vind, maar 
mense is moeg om op hulleself te fokus en die rekordverkope dui op twee dinge (i) Sekularisme bevredig nie meer nie, en (ii) ons hoef nie ons boodskap aan te pas by elke jota en titel van moderniteit om 'n gehoor te kry nie.

Die boek bestaan uit 40 dagstukke en die leser word gemaan om nie meer as een dagstuk per dag te doen nie (Warren 2002:9). Hy motiveer die 40 dagstukke deur te noem dat God 40 dae as 'n belangrike geestelike tydperk beskou. God gebruik 40 dae wanneer Hy mense vir sy doelwitte voorberei. Enkele voorbeelde word genoem: Noag se lewe is deur 40 dae se reën verander; Moses was na 40 dae op die berg Sinaï 'n ander mens. Elia het verander toe God hom 40 dae se krag uit 'n enkele maaltyd gegee het; Jesus is deur 40 dae in die wildernis bemagtig vir sy bediening.

Die eerste sewe dagstukke van die boek handel oor die vraag: Wat op aarde doen ek nou eintlik hier? Daarna volg die 5 doeleindes, elk oor sewe dae versprei, behalwe die laaste doeleinde wat vyf dagstukke het.

\subsubsection{Jy is vir God se behae beplan (Verheerliking)}

Dag 9: "Wat laat God glimlag?" is hier ter sprake (Warren 2002:6-66). Warren (2002:60) begin deur te sê: "Dit is jou lewensdoel om God te laat glimlag." Hy verduidelik aan die hand van die volgende hoofpunte terwyl hy dit demonstreer uit die lewe van Noag: God glimlag ...

- Wanneer ons God volledig liefhet.

- Wanneer ons God ten volle vertrou.

- Wanneer ons God heelhartig gehoorsaam.

- Wanneer ons God gedurig prys en dank.

- Wanneer ons ons vermoëns gebruik.

'n Mens sou Barnard in hierdie verband kon aanhaal as hy praat van die erediens van die lewe:

Die wese van die erediens kan nie voldoende verstaan en beleef word nie as dit slegs gesien word soos dit op Sondag funksioneer. Die eintlike sin en betekenis daarvan kom tot openbaring wanneer die erediens van die Sondag waar word in die erediens van die lewe ... Aanbidding wat nie betrekking het op die daaglikse lewe nie, is onwerklik, lewensvreemd en kragteloos, en versuim sy ware doel.

(Barnard 1981:459)

Nel (1994:43) praat in hierdie verband van die toegesegde status van 'n Christen - wat ons in Christus gegee is (indikatief) en wat ons uit 
dankbaarheid geneem het, maak van ons wat ons is. Om te bestaan en selfstandig geestelik te funksioneer, vra dat die gelowige moet wees (imperatief) wie hy in Christus is. Nel (1994:37) noem ook dat alle diens in die gemeente veranker is in die dienswerk van Christus. God se "diens" aan die mens het so mens geword dat die gemeente voor die keuse gestel word om ook so mens te word. Hy noem dat God juis gedien word deur die diens aan mense. Godsdiens en naastediens hoort bymekaar. Hoe eerliker die Godsdiens in die erediens is, hoe meer logies vloei die naastediens as deel van ons Godsdiens daaruit voort. God die Vader, Seun en Gees word op hierdie wyse ver-Heer-lik (Nel 1994:37-38).

Warren (2002:58) laat ver-Heer-liking oorloop in die alledaagse deur dit te noem dat aanbidding nie net vir eredienste is nie. Behalwe pertinente naastediens, is die uitleef van talente en vermoëns aanbidding:

Jy reken miskien God het net in jou 'n behae wanneer jy 'geestelike' dinge doen - Bybel lees, kerk bywoon, bid of jou geloof met iemand deel ... Elke menslike bedrywigheid (behalwe sonde) kan God behaag as jy dit met 'n houding van lof uitvoer. Jy kan skottelgoed was, iets regmaak, 'n produk verkoop, 'n rekenaarprogram skryf, 'n gewas verbou en 'n gesin grootmaak alles tot eer van God. Soos 'n trotse ouer kyk God veral hoe jy die talente en vermoëns wat Hy jou gegee het, gebruik. God het elkeen doelbewus verskillende gawes gegee sodat Hy dit kan geniet. Hy het gesorg dat sommige atleties is, en ander ontledend. Jy het dalk gawes as 'n werktuigkundige of wiskundige of musikant of een van 'n duisend ander vaardighede. Al dié vermoëns kan God laat glimlag.

(Warren 2002:64-65)

Hierdie sewe dagstukke gaan hoofsaaklik oor die indiwidu se verhouding met God wat met die term aanbidding beskryf word. In hoofsaak kom aanbidding (Warren 2002:55-99) neer op die volgende:

- $\quad$ Aanbidding in die erediens (Dag 8-10).

- $\quad$ Aanbidding as vervulling van jou lewensdoel (Dag 11-12).

- $\quad$ Aanbidding as gesindheid van oorgawe en aanbidding as gebed (Dag 13-14).

\subsubsection{Jy is vir God se familie geskep (Onderlinge sorg)}

Volgens Mead (1996:46) het die mense in Amerika na die tweede

Wêreldoorlog na die stede toe gestroom: "It was a search not only for a house 
and a plot of ground, but also for the myth of close-knit human community ..." Tans woon $50 \%$ van die wêreld se bevolking reeds in stede. Teen die jaar 2025 behoort daar ongeveer 93 groot wêreldklas stede te wees waarvan 80 in ontwikkelende lande sal wees (George 1992:20-22). Dit blyk dat die soeke na gemeenskap in die stede, vir die meeste 'n ontnugterde ervaring is. Mense wil hulle woonbuurte steeds sien as 'n bron van gemeenskap maar, soos Mead (1996:46) tereg opmerk: "Neighbour is often the new word for stranger."

Die Saddleback Church van Rick Warren is in Lake Forest, Kalifornie (Purpose Driven Life 2002-2005) geleë en soos bo genoem is daar by die verstedelikte mense 'n soeke na gemeenskap. Warren (2003) se tweede doel is "Jy is vir God se familie geskep". Dit is ook die woorde waarmee hy dag 15 begin (Warren 2003:103). Die hele saak van God se familie word uitgebou in 7 dagstukke en sluit die volgende in:

- $\quad$ God se familie (Dag 15).

- $\quad$ Liefde - die belangrikste deel van ons lewe (Dag 16).

- $\quad$ Lidmaatskap van 'n kerk (Dag 17).

- $\quad$ Gemeenskap van gelowiges en die uitbou daarvan (Dag 18-21).

\subsubsection{Jy is geskep om soos Christus te word (dissipelskap)}

Die woord dissipel het in die Griekse wêreld die betekenis van vakleerling gehad. Hierdie gedagte gryp terug na die Griekse werkwoord manthanein wat beteken om jou gedagtes op iets te fokus. Die werkwoord vir "volg", akolouthein kan volgens kenners ook op dissipelskap dui. Die kwessie van onderrig was vir Jesus belangrik gewees, maar sy bedoeling was nie net om inligting oor te dra nie, maar om 'n onvoorwaardelike oorgawe aan, en verbondenheid met Hom wakker te maak. Die Griekse woord vir dissipel, mathytys beteken, behalwe "vakleerling", ook ywerige navolger, selfs om nabootser van 'n leraar te wees (Nel 1994:85-86).

Miller (1994:16) noem 'n dissipel iemand wat met God wandel, die Woord leef, bydra tot die werk en 'n impak het op die wêreld. Dit kan gesê word dat elkeen wat in 'n verhouding met Jesus Christus leef ' $n$ dissipel is. Elke dissipel is ook lid van die liggaam van Jesus Christus. 'n Mens sou kon sê dat Christenskap $=$ dissipelskap = lidmaatskap van die liggaam van Jesus Christus (Nel 1994:84).

Die term dissipelskap word nie deur Warren (2003:151-196) gebruik in 'n opskrif nie. Hy begin sy sewe dagstukke met die opskrif en inleidingsin: "Jy is geskep om soos Christus te word" (Warren 2003:150-151). Die hele saak van dissipelskap val in die volgende eenhede uiteen: 
- $\quad$ Die motivering vir dissipelskap (Dag 22 en 23).

- $\quad$ Die rol van die Bybel in dissipelskap (Dag 24).

- $\quad$ Gevorm deur probleme en versoekinge (Dag 25-27).

- $\quad$ Dissipelskap - 'n lewenslange proses (Dag 28).

\subsubsection{Jy is geskep om God te dien (Bediening)}

Gibbs (1981:313) het die volgende uitspraak gemaak oor lidmate en bedieninge: "Church Growth cannot be sustained unless the laity are mobilised to fulfil their distinctive ministries both in the Church and the world." Volgens Van der Spuy (2004:155) wil mense wat geestelik onvolwasse is net ontvang en bedien word. Vir baie is dit genoeg om net die eredienste by te woon en te ontvang. Hulle het geen behoefte om uit te reik of betrokke te raak by gemeenskapsdiens nie. Nel (1994:237) noem tereg dat die gemeente ten diepste God se mense is wat God in hierdie wêreld dien en verteenwoordig. Strukture van die bedieninge is vorme van die funksies van mense in diens van God. Hy noem dat die bepalende die funksie is wat vervul moet word, nie die strukture of vorm wat mettertyd van middele tot doeleindes op sigself word nie. Strukture is diensbaar aan die doel waarvoor hulle geskep is. Hulle word nie die doel nie (Nel 1994:238). Strukture en vorm kan maklik lei tot wat Warren (2003:203) 'n "bedien my" of "Ek soek 'n kerk wat my behoeftes bevredig en my seën" houding noem. Hy (Warren 2003:202) praat van 'n indruk sonder 'n uitdrukking wat 'n teneerdrukking veroorsaak. Studie sonder diens beteken geestelik stagnasie: Die laaste ding wat talle gelowiges deesdae nodig het, is nog Bybelstudie. Hulle weet reeds baie meer as wat hulle in die praktyk toepas. Hulle het dien-ervarings nodig waar hulle hul geestelike spiere kan bult.

Hierdie doeleinde verteenwoordig 'n waardvolle en praktiese uiteensetting van ' $n$ Christen se diens. Dag 29 bied 'n soort begronding van dienslewering terwyl Warren (2003:206-218) in Dag 30-32 'n akroniem, SHAPE gebruik om gelowiges te motiveer vir diens in die wêreld.

Sielsgawes
Hart
Aanleg
Persoonlikheid
Evaring

Die woord "sielsgawes" is geforseerd en vreemd aan Afrikaans maar word ter wille van die akroniem verduur. 'n Beter woord sou eerder "genadegawe" (HAT:2000:273) kon wees. Dag 33-35 is 'n verdere verduideliking oor die doen en denke van 'n ware dienaar. 


\subsubsection{Jy is vir ' $n$ sending geskep (evangelisasie)}

"There is a famine of hope" (Newbigin 1994:41). Newbigin het hierdie woorde gebruik toe hy na sy Winson Green ministry (1987-1988) verwys het. Dit was 'n klein gemeentetjie in Birmingham en sy antwoord op die "famine of hope" "We have good news to tell." Maar dan met 'n vermaning aan die Kerk in die middestad:

It is not communicated if the question uppermost in our minds is about the survival of the Church in the inner city ... if our "evangelism" is at bottom an effort to shore up the tottering edifice of the Church (and it sometimes looks like that), then it will not be heard as good news. The church is in God's keeping. We do not have the right to be anxious about it. We have our Lord's word that the gates of hell shall not prevail against it.

(Newbigin 1994:41)

Met die regte motiewe in gedagte vra Newbigin (1994:42) die vraag na die beste manier om die evangelie geloofwaardig oor te dra aan mense wat klaarkom sonder God. "I know of only one clue to the answering of that question, only one real hermeneutic of the gospel: congregations that believe if' (eie kursivering).

Bosch (1991:48-49) noem dat gelowiges deur God gestuur om geografiese, religieuse en sosiale grense oor te steek. In 'n sin was die vroeë kerk polities rewolusionêr. Dan word daar nie onder rewolusie verstaan dat dit met een of ander vorm van geweld gepaard gegaan het nie. Dit was eerder oor die alternatiewe wat dit gebied het. Die gode van die heidense wêreld is verwerp; nuwe verhoudinge het ontstaan wat rewolusionêr was - Jood, Romein, Griek, vryman en slaaf, ryk en arm, man en vrou het mekaar aanvaar as broer en suster in Christus. Die nuwe taal van Christene was die taal van liefde wat nie net lippetaal was nie, maar 'n aksie van liefde en dade. Newbigin (1991:42) praat van die "believing congregation ... scattered throughout the community to bear the love of God into every secular happening and meeting. It is they who scatter the seeds of hope around ...."

Newbigin (1958:21; 43; aangehaal in Bosch 1991:373) onderskei tussen die kerk se sendingintensie en sendingdimensie. Sendingdimensie het te doen met die werksaamhede van die gemeente waar lidmate toegerus word vir hulle roeping in die samelewing en waar die strukture plooibaar en innoverend is. Alle werksaamhede van die kerk behoort 'n sendingdimensie te hê. Sendingintensie reik uit na anderkant die mure van die kerk en raak betrokke in missionêre "punte van konsentrasie" soos evangelisasie en werk 
vir vrede en geregtigheid. In 'n gemeente behoort beide hierdie sake aanwesig en werksaam te wees.

Die missionêre sluit ook meer in as bogenoemde, dit is ook kerk met ander kerke. Die kerk bestaan nie net vir homself nie maar ook vir hulle wat buite die kerk is (Bosch 1991:375). Saam met ander word daar aan die intensie gewerk om hulle wat "buite" is, te bereik. Die kerk is ook Missio Dei, die drie-enige God wat die kerk die wêreld instuur. Sending het sy oorsprong in die hart van God, Hy is die fontein van sendende liefde. Daarom kan die kerk nie anders as om 'n evangeliserende kerk te wees nie. Evangelisasie begin plaaslik en kring wyer (Getz 1984:69-81), van die spreekwoordelike Jerusalem, sowel as in die hele Judea en Samaria, tot aan die uithoeke van die wêreld. Hierby inbegrepe, ook die sending aan hulle van ander godsdienste.

Mead (1996:69) noem dat sending (evangelisasie ingesluit) tot op hede baie institusioneel verstaan is. Dit is meestal die leierskap van die gemeentes wat evangelisasie inisieer en bestuur. Die uitdaging voor die kerk se deur, is soos Mead dit stel: "The church of the future must become fully apostolic (vgl Gibbs 2000:51). It must be an apostolic people, not an apostolic institution or hierarchy. Each member of the church must see him- or herself as being an apostle." Mead stel dat daar duidelik onderskei moet word tussen "Apostolic People" en 'n "Apostoliese Kerk". Laasgenoemde dra die kiem in hom dat die missionêre die religieuse kant van kerklike imperialisme word wat uitloop op 'n "top-down" situasie. Apostoliese mense besef dat sending God se sending is waarvan hulle deel kan wees. Dit beteken dat elke lidmaat van die gemeente betrokke by sending moet wees, die hele tyd en oral (Mead 1996:80).

Volgens Dulles (1987:89) in sy hoofstuk oor die kerk as dienskneg, is die kerk die aktiewe subjek en die wêreld die objek, met wie die kerk werk en probeer beïnvloed. Hy sluit by Bonhoeffer (1967:203) aan wat gesê het: "Die kerk is alleen kerk as dit vir ander bestaan ..." Armstrong (1979:38) sluit hierby aan as hy sê: "If there is one image in the Bible that expresses the mission of the church, it is that of a servant."

Armstrong (1979:47) spesifiseer hierdie dienskneg gestalte van die kerk deur te wys dat die kerk daar moet wees waar daar konflik is, om 'n instrument van versoening te wees; waar daar onreg is, moet die kerk die instrument vir hervorming wees; waar daar lyding of bepaalde behoeftes is, moet die kerk 'n gemeenskap wees waar daar medelye is en moet die behoeftes van mense in nood aangespreek word "in whatever ways are possible"; Waar daar korrupsie is, moet die kerk 'n simbool wees van God se oordeel oor die euwels van die gemeenskap en 'n getuie van die waarheid; waar 'n persoon afgesonder is van 'n ander persoon, groep van 'n ander 
groep, ras van 'n ander ras, nasie van 'n ander nasie moet die kerk 'n demonstrasie wees van God se liefde en sy eenheid in Christus.

Daar is ook ander skrywers wat aansluit by hierdie saak van die "dienskneg gestalte" van die kerk. Callahan (1983:1) se eerste kenmerk van 'n suksesvolle kerk is spesifieke, konkrete missionêre doelwitte. Daarby bedoel hy 'n gemeente wat fokus op spesifieke "human hurt and hope" soos byvoorbeeld hulp aan alkoholiste en hulle families. Die gedagte is dat 'n gemeente met sulke doelwitte werklike diens aan 'n gemeenskap sal lewer en in daardie diens ook 'n missionêre gerigtheid sal hê. In hierdie benadering moet daar gewaak word om nie alles vir almal te wees nie: "The church that does that, ends up helping no one with anything."

Sjogren (1993:17) gee 'n definisie van wat hy "Servant Evangelism" noem: "Demonstrating the kindness of God by offering to do some act of humble service with no strings attached." Ook Sider et al (2002:45) in hulle boek: Churches that make a difference, pleit vir betrokkenheid in die wêreld, maar dan vanuit ' $n$ holistiese benadering. In hoofstuk 2: The church's calling to holistic ministry word die volgende gesê: "To spread the kingdom of God is more than simply winning people to Christ. It is also working for the healing of persons, families, and relationships. It is doing deeds of mercy and seeking justice." Dit is teen hierdie agtergrond dat daar na Warren (2003:247-267) verwys word ten opsigte van dae 36-38. Die volgende kan opgemerk word vanuit hierdie Doeleinde: "Jy is vir 'n sending geskep."

Warren (2003:247) onderskei tussen die bediening en sendingbetrokkenheid van die gelowige: Jou bediening (Doeleinde 4) is jou diens aan gelowiges en jou sending (Doeleinde 5) is jou diens aan ongelowiges. Die vraag is wat presies met die woorde: "diens" aan ongelowiges bedoel word? Uit dag 36 blyk dit dat "diens" neerkom op 'n gelowige wat evangeliserend in die wêreld aan die werk is. Warren (2003:248-253) koppel dit aan die Groot Opdrag van Jesus wat deur elke gelowige uitgevoer moet word. Hy noem dat elke gelowige se sending 'n wonderlike voorreg is, dat die goeie nuus aangaande verlossing en ewige lewe gedeel moet word. Behalwe dat jou sending van ewige belang is gee dit ook betekenis aan jou eie lewe.

In die hoofstuk: Word 'n wêreldklas-Christen (Warren 2003:264) moedig hy gelowiges aan om by ' $n$ korttermyn-sendingprojek na ' $n$ ander land aan te sluit. Warren (203:265) noem dat so 'n projek 'n positiewe uitwerking op die gelowige het: "Dit gaan jou hart laat swel, jou visie verbreed, jou geloof groter maak, jou mededoë versterk en jou met die soort vreugde vul wat jy nog nooit ervaar het nie. Dit kan die keerpunt in jou lewe wees." 


\subsection{Waardering}

Wat is dit wat die Purpose Driven Life (2002) so gewild maak? Dit kan aan 'n verskeidenheid faktore toegeskryf word:

- Rick Warren was reeds by sommige predikante en lidmate bekend vanweë sy eerste boek, The purpose driven church (1995). Die geweldige sukses wat hy met die Purpose driven paradigma gehad het het hom reeds ' $n$ groot mate van geloofwaardigheid gegee (Ungerer 2006:6).

- Sy geloofwaardigheid as pastor en mens is ook bo verdenking by van sy felste kritici: "Rick Warren is undoubtedly a sincere and personable Christian leader, and his book if full of important, practical truths truths that present day believers often tend to ignore or forget" (Costella 2004:2). Jonson (s a:1) merk op: "I have no intention of calling into question Rick Warren's motives. I have no reason to believe that he doesn't love God, his church and the unsaved. There is nothing in his life that leads me to believe he is a wolf in sheep's clothing."

- Die 40 dae veldtog waaraan die boek gekoppel is maak dit 'n aantreklike opsie vir gemeentes wat gedurig maniere soek om lidmate toe te rus en herlewing te bewerkstellig. Die onmiddellike resultate dra by tot die gewildheid van die veldtogte. Een predikant in die Ring van Klerksdorp het soos volg opgemerk: “... die interessante is die gemarginaliseerde lidmate wat amper meer daaruit geput het as die kerngroep. Waarskynlik te wyte aan hulle onbetrokkenheid in die verlede" (Ungerer 2006:116).

- Warren gaan uit sy pad om geen denominasie aanstoot te gee nie. Trouens, die boek is "ekumenies vriendelik", daarvan getuig die lang lys van denominasies in Suid-Afrika wat reeds die veldtog deurloop het. Name soos die Shalom Gesinskerk en die Norwegian Settlers Church val dadelik op (Ungerer 2006:123).

- Die eenvoudige konsep van die 5 doeleindes wat in die boek uitgewerk is is logies en geloofwaardig. Predikante het al opgemerk: "Daar is niks nuuts aan die 5 punte nie, dit is só logies - hoekom het ék nie daaraan gedink nie?" 
- Die grootste waarde lê in die inhoudelike van die boek. Warren skroom nie om te sê dat alles by God begin en dat die mens uitsluitlik deur sy doel en vir sy doel gebore is nie. Bo en behalwe die geloofsinhoud, wemel die boek van praktiese waarhede en wyshede. Een só 'n voorbeeld is in dag 16 onder die opskrif: "Tyd is die beste uitdrukking van liefde." Hy noem dat tyd jou kosbaarste geskenk is, want jy het net soveel daarvan. Jy kan nog geld maak, maar jy kan nie meer tyd maak nie. Wanneer jy iemand jou tyd gee, gee jy hulle 'n stukkie van jou lewe wat jy nooit weer gaan terugkry nie. Jou tyd is jou lewe. Dis waarom jou tyd die grootste geskenk is wat jy iemand kan gee."

- Baie se lewe is positief verander en verryk deur die boek. Op die webtuiste http://www.purposedrivenlife.com is vele verhale van mense wat hiervan getuig.

\subsection{Skrifgebruik?}

Die BusinessWeek Online van 23 Mei 2005 haal Warren aan waar hy homself en sy kerk as "Evangelical" posisioneer. Die tradisiestroom wat ons evangelies noem, is 'n taamlik gevarieerde stroom wat met die Piëtisme en Revivalisme verband hou, en baie klem word gelê op die belewenis van die godsdiens (Nicol 2000:12). Wat hier van belang is is die eie siening van die Evangelicals dat die Bybel letterlik die woord van God is. BusinessWeek Online (2005) beskryf dit soos volg:

Rick Warren, senior pastor of Saddleback Church in California and arguably the nation's most influential evangelical pastor - says evangelicals are united by three characteristics: "They believe that the Bible is literally God's Word, that Jesus Christ is God ... and that we have a responsibility to pass this good news on to other people".

Warren maak van meer as 1200 aanhalings uit verskillende Bybelvertalings gebruik om sy redevoeringe te staaf. Chritianity Today in 2004 noem dat Warren aanhoudend tekste uit konteks aanhaal om sy punt te staaf. Hy maak ook graag van parafrases gebruik. Kritici soos B Jonson (s a:par 3) lewer skerp kritiek: "He misuses scripture to such a degree that I question whether he had a single course in Biblical hermeneutics."

'n Voorbeeld van Warren se hermeneutiese omgaan met die Bybel is by Dag 15 waar hy die noem dat ons vir God se familie geskep is. Die oomblik toe ons in God se familie ingebore is, het ons 'n klompie verstommende verjaarsdaggeskenke gekry: Die familienaam, die familie-ooreenkoms, die 
familie voordele, intieme toegang tot die familie, en die familie erfenis! Hy bou voort op die gedagte van die erfenis en noem onder andere dat ons beloon gaan word en posisies van diens gaan kry. Dit is veral dié: "... en posisies van diens kry", wat die wenkbroue laat lig. Wat word daarby bedoel? Vier teksgedeeltes verwys: Markus 9:41; 10:30; 1 Korintiërs 3:8; Hebreërs 10:35 en Matteus 25:21, 23. By al hierdie tekste is daar nog 'n saak uit te maak van beloning wat aan die ewige lewe gekoppel kan word. Maar nêrens is enige aanduiding van posisies van diens in die hiernamaals nie. ' $n$ Voorbeeld van verdagte hermenieutiek (vgl Costella 2004:3; Chritianity Today 2004:29; Jonson s a: par 3; McMohan s a: par 4; Ungerer 2006:137-139).

\subsection{Doktrine}

Die veiligste invalshoek hier is om te redeneer dat Warren (2002) juis so min as moontlik aan leerstellige sake aandag wil gee omdat hy nie in ekumeniese verband aanstoot wil gee nie. Dit haal hom kritiek op die hals uit Christen fundamentalistiese oorde soos onder andere David Cloud van die Fundamental Baptist Information Service. Cloud (2005: par 3) se artikel gaan onder die naam "Rick Warren's dangerous judge not ecumenism": "His book The purpose driven life contains extensive documentation of his dangerous an unscriptural 'judge not' ecumenical philosophy." Cloud (2005: par 8) kritiseer Warren se opmerking (2002:34) waar hy sê dat God nie sal vra na ons religieuse agtergrond of leerstellings nie. Ook Costella (2004:8) voel dieselfde:

Noticeably absent from Warren's book is any emphasis on the need for personal holiness and purity of doctrine. Certainly, in any believer's spiritual journey, pure doctrine is vitally important, for the only truths anyone knows about God and the process of living the Christian life stem from the teaching (doctrine) of God's Word ... Warren, however, never warns the believer to watch out for false doctrine or harmful fellowships - in fact, he minimizes the need for doctrinal purity by stressing the importance of 'love' en 'unity' above anything that would cause strife or division.

Dit is nogal moeilik om met die eerste oogopslag foute in Warren se boek raak te sien. Die meeste dinge klink so goed en reg. Die probleem is dat hy net op sekere aspekte van die Christendom fokus en dit word positiwisme genoem (Malan s a: par 6). Sy groot strewe na ekumeniese eenheid ten koste van leersuiwerheid, vervreem hom van die meer behoudende teologiese groeperinge. Van dié sake word kortliks na verwys: 
- Daar word te min gemaak van skuldbelydenis en berou juis vanweë die positiwistiese aanslag (Christianity Today 2004:1; vgl Costella 2004:7; Kjos 2003:7; Malan s a: par 3). Bennet (2005:4) stel dit skerp: "A sinner ought not to be comforted by assurances of the love of God apart from repentance and faith in Christ. Rather a sinner should be reminded that God hates sinners as Scripture insists."

- Sommiges voel dat daar te min gemaak word van die versoenende werk van Christus (Christianity Today 2004:1). Tog maak die skrywer 'n positiewe opmerking: "Then again, he does introduce the centrality of Christ in chapter one, a marked improvement over popular Christian bestsellers of the past like Robert Schuller's books on possibility thinking"

- Die vraag word tereg deur Costella gevra (2004:14) of die 5 doeleindes van Warren (2002) die belangrikste is. Volgens hom is daar net een doel: "The Bible only declares one purpose for mankind's existence: to glorify God." Die 5 doeleindes is volgens Costella die maniere hoe God verheerlik word: "But the means by which a believer glorifies God must never become the purpose for existence, for in such an instance, it is possible for the means to conflict with the purpose".

- Die liefde van God word oorbeklemtoon ten koste van sy geregtigheid. "Warren's type of God, who loves everyone as a special object of His love, is utter heresy. Love apart from His righteousness is not the essence of Gods character. Rather in Scripture God's saving love is always in accord with His righteousness" (Bennet 2005: 2). Ook Kjos kan in hierdie verband aangehaal word:

The problem is not that pastor Warren left out "the fear of God". He can't possibly teach all God's instructions in one book. The problem is lack of balance. By emphasizing God's delight in "every detail of your life" through most of the book while rarely mentioning God's anger, holy standard or judgement, he virtually denied the less comforting side of God's nature."

(Kjos 2003:21)

- Die verwysing na die Christen se doop is vanuit die raamwerk van die volwasse doop. Hoewel dit subtiel gedoen word kan dit tog 
onsekerheid skep by lidmate met 'n Gereformeerde doop- en verbondsbeskouing (Ungerer 2006:6).

- Warren se beskouing oor kerkmusiek asook die wyse waarop dit in sy gemeente gedoen word, ontlok hewige kritiek by sommiges. Daar is al na Saddleback verwys as: "The flock that likes to rock." Warren (in Costella 1998:6) praat só daaroor:

So, we made a strategic decision that we are unapologetically a contemporary music church. And right after we made that decision and stopped trying to please everybody, Saddleback exploded with growth. Now, l'll be honest with you, we are loud. We are really, really loud on a weekend service .... I say, 'We're not gonna turn it down".

\section{DIE 40 DAE DOELGERIGTE LEWE VELDTOG IN DIE RING VAN KLERKSDORP}

Die studie berus op die hipotese dat die 40 Dae doelgerigte lewe veldtog 'n uitstekende projek vir gemeentes om hulle bestaansdoel te ontdek terwyl dit ook dien tot versterking en uitbouing van die gemeentebouproses by gemeentes wat reeds met gemeentebou besig is. Om hierdie rede is daar besluit om kwantitatiewe sowel as 'n deel kwalitatiewe navorsing te doen ten einde vas te stel of die hipotese standhou. Soos uit ondergenoemde blyk dit dat die veldtog elders in die land met groot vrug gebruik is.

In Suid-Afrika het 532 gemeentes en kerke teen 2006 reeds die Doelgerigte lewe pakkette aangekoop, die veldtog deurloop of beplan om dit te doen. Sommiges praat in verkorte vorm van die Fokus 40. Purpose Driven Ministries South Africa (PDMSA) noem dat die 40 dae veldtogte die volgende resultate in deelnemende gemeentes tot gevolg gehad het:

- Erediensbywoning het met 34\% verbeter gedurende die veldtog.

- Die aantal kleingroepe het met $183 \%$ vermeerder.

- Aantal bedieningsvrywilligers het met $63 \%$ toegeneem.

- Aantal bedieninge het met $22 \%$ gegroei.

\subsection{Kwantitatiewe navorsing}

Die Ring van Klerksdorp het in Maart 2004 besluit om 'n Doelgerigte lewe veldtog te loods vanaf 11 Augustus tot 19 September 2004. Agt van die elf gemeentes het deelgeneem. 'n Totaal van 1562 (25\%) uit 'n potensiële 6327 
persone het deelgeneem waarvan verreweg die meeste, lidmate van die agt gemeentes was. Van die lidmate wat deelgeneem het aan die veldtog, het 171 opgetree as respondente vir 'n vraelys wat oor die veldtog gehandel het. Die predikante van die deelnemende gemeentes het almal opgemerk dat daar 'n definitiewe styging in erediensbywoning was gedurende die 40 dae periode. Daar het 29 kleingroepe in daardie tyd gefunksioneer terwyl daar ook 'n styging was in lidmate wat aangemeld het by bestaande bedieninge. Van die respondente het $73 \%$ getrou hulle dagstukkie gelees en $83 \%$ het 5 en meer eredienste bygewoon gedurende die wydingsperiode.

\subsection{Bestaansdoel?}

Soos vermeld, handel die eerste deel van die boek oor die vraag: Wat op aarde maak ek hier? Dit was 'n uitdaging om te bepaal in hoe 'n mate lidmate van die Nederduitsch Hervormde Kerk klarigheid het oor hierdie vraag en hulle bestaansdoel. Verreweg die meeste respondente het aangetoon dat hulle deelgeneem het uit soeke na betekenis. Van hulle, het $36 \%$ aangedui dat hulle gereeld gewonder het oor hulle bestaansdoel terwyl $52 \%$ net soms daaroor gewonder het. Dit is beduidend dat $95 \%$ aangedui het dat hulle na die veldtog oortuig is van hulle bestaansdoel as Christengelowiges. Dit blyk dat Warren daarin slaag om gelowiges aan die hand van die 5 doeleindes te begelei tot 'n groter besef van hulle bestaansdoel.

\subsection{Missionêre bewussyn}

Die besef van 'n bestaansdoel beteken nog nie die uitleef daarvan nie. Die toets hiervoor lê op die terrein van die missionêre. In hoe 'n mate is Hervormde lidmate bereid om met kerklos of ongelowige mense te praat? Die Doelgerigte lewe veldtog het sommiges meer vrymoedigheid gegee en $28 \%$ respondente het gewaag om met altesaam 154 kerklos en ongelowiges in Klerksdorp en elders in gesprek te tree. Daarteenoor het $72 \%$ respondente geen gesprek gevoer nie. Respondente het verder laat blyk dat 27 (18\%) van die 154 kerklos en ongelowiges met wie gesprek gevoer is, tot 'n geloofsbeslissing gekom het. Oor 42 is daar onsekerheid en by 57 was daar geen beslissing nie. Dit is onseker hoeveel van die bekeerlinge binne die Ring van Klerksdorp woonagtig is aangesien respondente ook op familie en vriende gefokus het wat elders woon. Dit is ook onseker hoe akkuraat die syfers in hierdie paragraaf is aangesien dit moeilik is om hierdie soort statistiek te kontroleer. Tog bestaan 'n redelike vermoede dat die veldtog en die boek meer gelowiges bemagtig het om missionêre betrokke te raak in kerklos en ongelowige mense se lewens. 


\subsection{Respondente se algemene indrukke van die veldtog.}

Die respondente kon een of meer uit 6 moontlikhede kies wat hulle algemene indrukke van die veldtog betref. Uit die 171 wat gereageer het is die volgende moontlikhede aangewys (Ungerer 2006:104):

Dit was ' $n$ absolute hoogtepunt in my lewe as Christen.

Ek weet nie of hierdie veldtog heeltemal vir my was nie.

Ek is vasberade om voortaan die 5 doelwitte doelgerig uit te leef. 79

(92 - geen kommentaar)

Ek dink die hele veldtog was oorwaardeer.

Ek verstaan meer as voorheen wat my bestaansdoel as Christen is.

Ek dink dit was 'n mors van tyd.

(58 - geen kommentaar)

Daar was 'n oorwegend positiewe belewenis van die veldtog. Daar is 5 wat gevoel het die veldtog was nie vir hulle nie. Dit is moeilik om vas te stel wat die bedoeling was van diegene wat geen kommentaar gelewer het nie. Sou dit wees dat hulle redelik neutraal gestaan het maar beslis nie negatief nie? Of was die vrae so gestel dat daar nie volle instemming by sekeres kon wees nie (Ungerer 2006:104)?

\subsection{Kwalitatiewe navorsing}

As deel van kwalitatiewe navorsing is die predikante van die Hervormde gemeentes in die Ring van Klerksdorp genooi om deel te wees van die ondersoek en moontlike deelname aan die veldtog (Ungerer 2006:106-118). Dit sou kon tuisgaan onder wat Denzin en Lincoln (1994:324-329) "cooperative inquiry" en "participatory action research" noem. Soos reeds genoem het 8 predikante die samewerking van hulle ouderlingevergaderings gekry en is begin om voor te berei vir die veldtog. Al die deelnemende predikante is uit die staanspoor betrek, hulle is ingelig dat navorsing daarby betrokke is, min of meer dieselfde riglyne is gevolg in die aanloop, die 40 dae veldtog het by al die gemeentes gelyktydig plaasgevind, die feeserediens is deur almal bygewoon, die vraelyste is onder almal se lidmate versprei en dieselfde vraelys is in al die gestruktureerde onderhoude gebruik (kyk Denzin \& Lincoln 1994:361-375). Uit die kwalitatiewe navorsing blyk dit dat al die predikante postief was oor die 40 dae veldtog. Die volgende alternatiewe is gestel waarby predikante kon antwoord (Ungerer 2006:116): 
7 Dit was een van die hoogtepunte in my bediening.

$0 \quad$ Ek dink dit was 'n mors van tyd.

8 Ek dink dit is 'n uitstekende hulpmiddel in 'n gemeentebouproses vir lidmate om hulle bestaansdoel te ontdek.

$0 \quad$ Ek dink die hele veldtog word oorwaardeer.

8 Ek sal beslis ander gemeentes aanmoedig om dieselfde deur te gaan.

0 Ek is nie seker of hierdie veldtog 'n verskil in my gemeente te weeg gebring het nie.

7 Die veldtog was vir my eie geloofslewe baie verrykend.

8 Ek gaan beslis my gemeente laat meedoen aan enige opvolgaksies wat hieruit voortspruit.

0 Die Doelgerigte Lewe Veldtog pas nie regtig in by ons Hervormde Kerk se etos nie.

Die woorde van 'n deelnemende predikant na afloop van die veldtog is dalk 'n gepaste afsluiting onder hierdie opskrif: "Daar was 'n nuwe belewenis van ou waarhede. Êrens het 'n pad tussen kop, hart en hande oopgegaan" (Ungerer 2006:113).

\section{GEVOLGTREKKING}

Hoe moet daar oor die werk van Warren en die 40 dae veldtog geoordeel word? Soos uit hierdie artikel blyk is daar baie positiewe sowel as negatiewe aspekte teenwoordig in Warren (2002) se werk. Geen mens en sy werk is bo kritiek verhewe nie. Die vraag is of al die kritiek teen Warren en sy werk die magdom positiewe aspekte ongeldig maak? My mening is dat die waarde van die boek en 40 dae veldtog, die gebreke oorskadu. Tog word predikante aangemoedig om die boek te lees aangesien lidmate wel na hulle mening sal vra. Naas die positiewe waarde van die boek, het die kritiese beoordeling dit ten doel om voornemende deelnemende gemeentes en kerke bewus te maak van die enkele gebreke. Dit is die pastor loci se voorreg en plig om die veldtog in te klee en aan te pas volgens die eie tradisie en etos.

Uit dit wat onder punt 4 gesê is blyk dit dat lidmate en predikante die eerste deel van die hipotesestelling bevestig. Respondente (95\%) het aangedui dat hulle na die veldtog oortuig was van hulle bestaansdoel op aarde. Sonder om die omvangryke saak van die gemeentebouproses te bespreek, word in die studie aangedui dat die vyf doeleindes wat Warren (2003) uitlig nie in die pad staan van die visie- en missieverklaring van 'n gemeente nie. Dit mag wel tydelik die aandag aflei van die koers wat'n gemeente ingeslaan het met gemeentebou, maar kan andersyds dien as 
bevestiging dat 'n gemeente wel op die regte koers is, al het dit net op enkeles van die 5 doeleindes betrekking. Die bevinding is dat die 40 dae veldtog in die Ring van Klerksdorp, oor die algemeen wel gedien het tot versterking en uitbouing van 'n gemeentebouproses in gemeentes wat besig is met gemeentebou of waar daar by die predikant 'n sterk gemeenteboufilosofie teenwoordig is. Volgens die hipotese waarop die navorsing (Ungerer 2006) berus, en in hierdie artikel weergegee blyk dit dat: Die 40 Dae Doelgerigte Lewe Veldtog is 'n uitstekende projek vir gemeentes om hulle bestaansdoel te ontdek terwyl dit ook dien tot versterking en uitbouing van die gemeentebouproses by gemeentes wat reeds met gemeentebou besig is.

\section{Literatuurverwysings}

Armstrong, R S 1979. Service Evangelism. Philadelphia, PA. Westminster.

Barnard, A C 1981. Die Erediens. Pretoria: NG Kerkboekhandel.

Bennet, R 2005. The purpose driven life: Demeaning the very nature of God.

[Online]http://www.bereanbeacon.org/articles/rick_warren_purpose_driven_2. htm [2005, July 1]

Bonhoeffer, D 1967. Letters and papers from prison, rev ed. New York. Macmillan.

Bosch, D J 1991. Transforming mission: Paradigm shifts in theology of mission. New York: Orbis Books.

Bradshaw, P 2006. Living with purpose (Rick Warren). CCNews Portal. http://www. CCNews portal.org [2006, August 12].

BussinessWeek Online 2005. Getting your religious terms right. [Online] http://www.businessweek.com/magazine/content/05_21/b3934017_mz001.ht m. [2005, July 8].

Callahan, K L 1983. Twelve keys to an effective church. San Francisco, CA: Harper.

Christianity today, 2004. Forget your bliss: The success of The purpose-driven life reveals a cultural opportunity, V 48, Jan-Jun, p 29.

Cloud, D 2005: Rick Warren's dangerous judge not ecumenism [Online] http://www.wayoflife.org/fbns/rickwarren-judgenot.html [2005, July 2].

Costella, D 1998. The church growth movement: An analysis of Rick Warren's "Purpose driven" church growth strategy. Foundation Magazine, March-April 1998, p 1-15

Costella, M 2004. An analysis of Rick Warren's The purpose-driven life [online].http://www.fundamentalbiblechurch.org/Foundation/fbcAnalysis.htm [2005, July 1].

Denzin, N K \& Lincoln, Y S 1994. Handbook of qualitative research. SAGE.

Dulles, A 1987. Models of the church: Expanded edition. New York. Doubleday.

George, C F 1992. Prepare your church for the future. Grand Rapids MI. Fleming H Revell.

Getz, G A 1984. Sharpening the focus of the Church. Canada: Victor Books.

Gibbs, E 1981. I believe in church growth. Grand Rapids, MI. Eerdmans.

Gibbs, E 2000. ChurchNext: Quantum changes in how we do ministry. Downers Grove, IL: Intervarsity Press. 
Jonson, B s a. Sonder jaar. An examination of Rick Warren's teaching on

"Exponential growth". Http://monergism/thethreshold/articles/questions/Rick WarrenGrowth.html. [2005, July 1]

Kjos, B 2003. Spirit - Led or purpose driven? [Online] http://www.crossroads.to/ 2003//1-purpose.htm. [2005, July 5]

Malan, J s a. Rick Warren waters down the Gospel [Online] http://www. bibleguidance.co.za/Engarticles/Rick.htm [2005: July 5].

McMahon, T A s a. Critique of Rick Warren's - The purpose-driven life. [Online] http://www.thebereancall.org [2005, July 4].

Mead, L B 1996. Five challenges for the once and future church. Wachington, DC: Alban Institute.

Miller, H 1994. Connecting with God: 14 Ways churches can help people grow spiritualy. Nashville, TN. Abingdon.

Nel, M 1994. Gemeentebou. Halfway House: Orion.

Newbigin, L 1994. A word in season: Perspectives on Christian world missions. Grand Rapids, MI. Eerdmans.

Nicol, W 2000. Godsdiens wat werk: Ontdek die soort godsdiens wat vir jou die beste werk. Wellington: Lux Verbi, BM.

Odendal, F F \& Gouws R H 2000. HAT: Verklarende Handwoordeboek van die Afrikaanse Taal, Vierde uitgawe, derde druk. Johannesburg: Perskor.

Sider, $\mathrm{R} \mathrm{J}$ et al 2002. Churches that make a difference: Reaching your community with Good News and Good Works. Grand Rapids, MI: Baker Books.

Sjogren, S 1993: Conspiracy of kindness: A refreshing new approach to sharing the love of Jesus with others. Ann Arbor, Ml: Vine Books.

Purpose driven life, 2002-2005. [Online] http://www.purposedrivenlife. com/rickwarren.aspx. [2005: July 2]

Stafford, T 2002. A regular purpose-driven guy. Christianity Today, Jul-Dec 2002, p 42-48.

Ungerer, A G 2006. 'n Praktiese teologiese studie vanuit 'n gemeentebouperspektief om die uitwerking te bepaal van die "40 Dae Doelgerigte Lewe" van Rick Warren as hulpmiddel in die Hervormde gemeentes van die Ring van Klerksdorp ten einde hulle bestaansdoel te ontdek. MA-verhandeling, Universiteit van Pretoria.

Ungerer, A G 2006. Rick Warren - profeet of dwaalleraar? Die Hervormer, 1 Junie, bl 6, 15 Junie bl 6, en 1 Julie 2006, bl 6 .

Van der Spuy, D 2004. Destined for growth: Towards a deeper spiritual life. Cape Town. Struik Christian Books.

Warren, R 1995. The purpose driven church, growth without compromising your message \& mission. Michigan, Ml: Zondervan.

Warren, R 2002. The purpose driven life. Michigan, MI: Zondervan.

Warren, R 2003. Die doelgerigte lewe. Jeppestown: Jonathan Ball. (Zondervan USA.) 